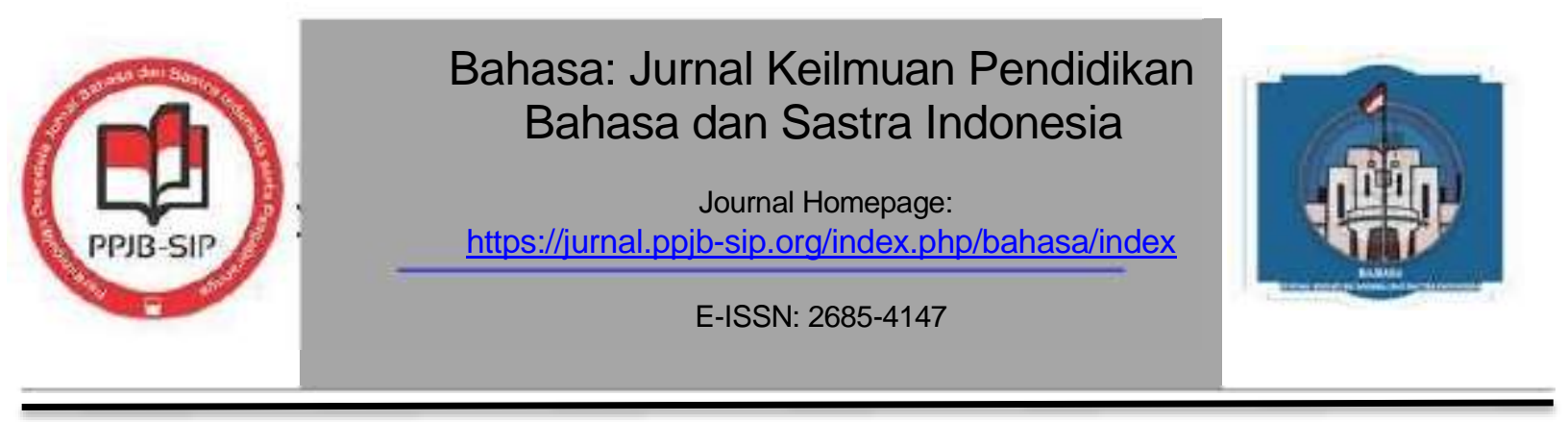

\title{
RELIGIOUSITY IN THE STORY “A DEER THAT ALWAYS REMEMBERS GOD": FABLE FROM SUNDA LAND
}

\section{RELIGIUSITAS DALAM CERITA "SEEKOR KANCIL YANG SELALU INGAT KEPADA TUHAN": FABEL DARI TANAH SUNDA}

\author{
Atisah \\ Badan Bahasa, Kemendikbud, Jalan Daksinapati Barat IV, Rawamangun, Jakarta Timur \\ atisah.shinutama@gmail.com
}

\begin{abstract}
This paper aims to analyze and reveal the values of religiosity in the animal story or fable "A Mouse Deer Who Remembers God". The method used is the descriptive analysis method and the theory used to analyze the work is an objective theory based on the work itself. In the very famous deer image, he is smart and always finds a solution when faced with problems. He often uses his senses well. In the story "A Mouse Deer Who Always Remembers God", the deer figure always gets a solution to every problem because he always remembers God. The author of the (anonymous) deer story seems to realize that even a creature (animal) always remembers God, what about us humans? By always remembering God life will be saved. This is the hidden message of the author. This fable genre does not only work as entertainment, it also has various functions such as didactic functions, advice, satire, and even social criticism.
\end{abstract}

Keywords: fable, religiosity, author's message

\begin{abstract}
Abstrak
Tulisan ini bertujuan untuk menganalisis dan mengungkapkan nilai-nilai religiusitas dalam cerita binatang atau fabel "Seekor Kancil yang Selalu Ingat Kepada Tuhan". Metode yang digunakan adalah metode deskriptif analisis dan teori yang digunakan untuk menganalisis karya adalah teori objektif yang bertumpu pada karya itu sendiri. Dalam fabel sosok kancil sangat terkenal, ia berwatak cerdik dan selalu mendapat solusi ketika menghadapi masalah. Ia sering menggunakan akal dengan baik. Pada cerita "Seekor Kancil yang Selalu Ingat Pada Tuhan", sosok kancil selalu mendapat solusi dari setiap masalah karena ia selalu ingat pada Tuhan. Pengarang cerita kancil (anonim) tersebut tampak menyadari, bahwa seekor makhluk (binatang) pun selalu ingat Tuhan, bagaiman dengan kita seorang manusia? Dengan selalu mengingat Tuhan hidup akan selamat. Inilah pesan tersembunyi pengarang.Genre fabel ini ternyata tidak hanya berfungsi sebagai hiburan, juga memiliki berbagai fungsi seperti fungsi didaktik, nasihat, sindiran, bahkan kritik sosial.
\end{abstract}

Kata kunci: fabel, religiusitas, pesan pengarang 


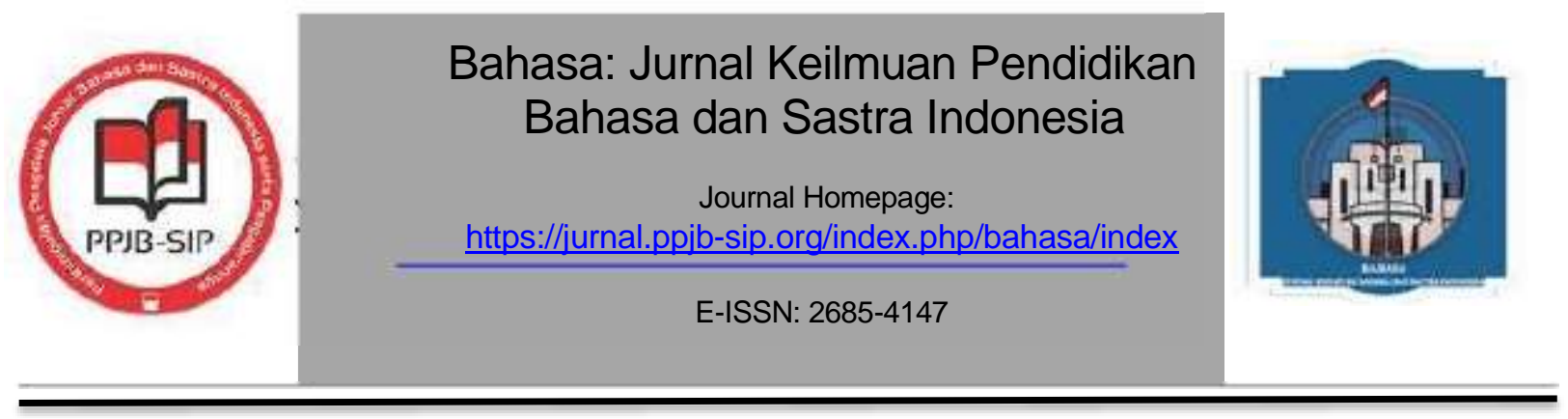

\section{PENDAHULUAN}

Indonesia Indonesia kaya akan cerita binatang atau fabel. Setiap daerah memiliki cerita binatang sebagai warisan nenek moyang secara turun temurun. Suku Sunda umumnya mengenal cerita binatang atau fabel seperti cerita kancil/pelanduk yang dalam bahasa Sunda ada yang menyebut peucang ada juga yang menyebut mengecek, babi hutan (bagong), burung (manuk), ikan (lauk), kura-kura (kuya), monyet, harimau/macan (maung), dan lain sebagainya.

Mardiyanto, (1999) telah mendata cerita kancil/pelanduk yang sudah dibukukan sekitar 22 cerita. Dia berpendapat bahwa cerita kancil/pelanduk dikenal sebagai salah satu cerita rakyat (lisan) yang memiliki banyak versi. Hampir setiap daerah di Nusantara mengenal dan memiliki cerita kancil, meskipun dalam judul yang berbeda. Berbagai judul cerita kancil yang terdapat di daerah Kepulauan Nusantara antara lain adalah (1) "Pelanduk Mata Kebul" dalam Sastra Lisan Melayu Belitung (Aliana, 1992:168); (2) "Kancil dengan Hantu (Harimau I)", (3) "Kancil dengan Hantu (Harimau II)", (4) "Kancil dengan Hantu (Harimau III)", (5) "Cerita Kancil dengan Siput", (6) Cerita Kancil dengan Kera", (7) "Cerita Kancil dengan Siput", dan (8) "Cerita Kancil dengan Rusa" dalam Sastra Lisan Simalungun (Damanik, 1986:83--114); (9) "Pelanduk Membalas Dendam" dalam Cerita Rakyat Daerah Kalimantan Tengah (Proyek Penelitian dan Pencatatan Kebudayaan Daerah, 1978/1979:135--140); (10) "Paa Paando Harimau" (Pelanduk dan Harimau) dalam Sastra Lisan Wolio (Mattalitti, 1985:28--28); (11) "Pelanduk Urum Canguit" (Kancil dan Canguit) dan (12) "Pelanuk" (Kancil) dalam Sastra Lisan Gayo; (13) "Lapung Palandok Siagang Lapung Buaya" (Pelanduk dengan Buaya) dalam Sastra Makasar Klasik (Rizal, 1993:144--148 dan 53--56); (14) "Cerita Si Pelanduk" dalam Cerita Rakyat Sulawesi Selatan (Proyek Penelitian dan Pencatatan Kebudayaan Daerah, 1981:97--104); (15) "Pulanduk Sibawa Macang" (Pelanduk dengan Macan) dalam Sastra Lisan Bugis (Fachruddin, 1981:89--91 dan 167--170) dan dalam Struktur Sastra Lisan Bugis (Sikki, 1996:92--99); (16) "Kancil dan Berang-Berang" dan (17) Si Kancil yang Cerdik" dalam Kumpulan Terjemahan Sastra Angkola Mandailing (Siregar, 1992:33--34 dan 109--120); (18) "Pelanduk Deket Danga-Danga" (Pelanduk dan Danga-Danga) dalam Sastra Lisan Dairi (Tinambunan, 1996:111--12 dan 157--158); (19) "Cerita Pelanduk dan Buaya" (Caritana Lopang Pulandok Siang Lapong Buaja) dan (20) "Kisah Pelanduk dengan Macan" (Caritana Lapong Pulandok Siagang Lapong Macang) dalam Rupama Cerita Rakyat Makasar (Hakim, 1991:32--65 dan 95--128); (21) "Kancil dengan Kera" dan (22) "Kancil dengan Buaya" dalam Tjerita Rakjat III (Urusan Adat-Istiadat dan Cerita Rakyat Jawatan Kebudayaan, 1963:124--135).

Secara umum kancil dalam ingatan kita merupakan binatang cerdik, dengan kecerdikannya, dia sering terlepas dari berbagai masalah yang melingkupinya walaupun kadangkadang dengan cara memperdaya binatang lain. Bahkan, ada juga yang memberi predikat kancil sebagai tokoh penipu, tokoh licik. Philip Frick Mc. Kean (Danandjaja, 2007) mengatakan bahwa, Kancil mewakili tipe ideal orang Jawa atau Melayu-Indonesia sebagai lambang kecerdikan yang 


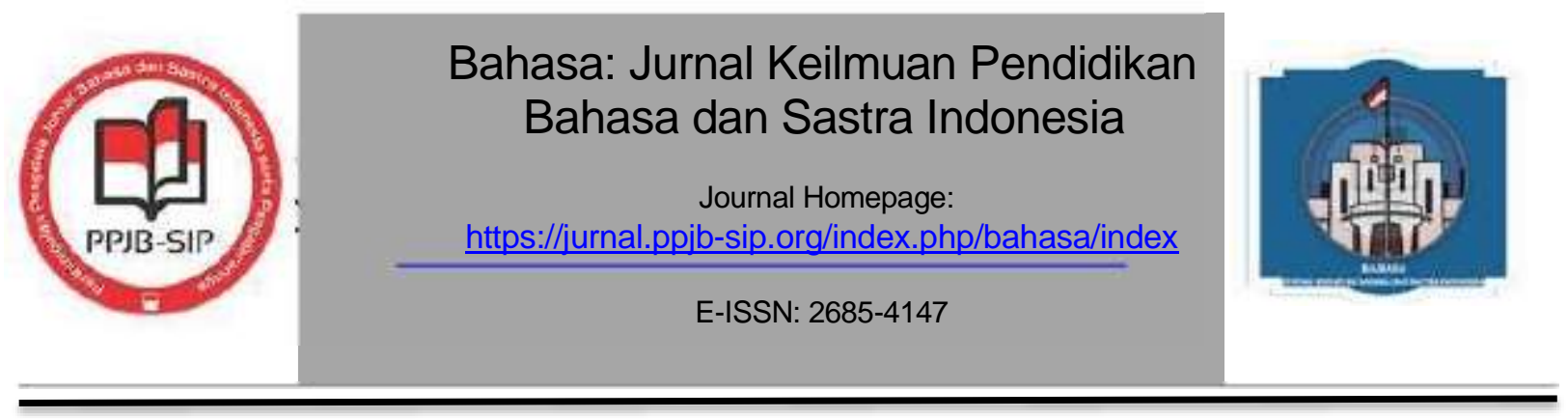

tenang/cool intelligence dalam menghadapi kesukaran selalu dapat memecahkan masalah yang rumit tanpa banyak ribut-ribut, tanpa banyak emosi.

Pada kesempatan ini, penulis mendapatkan data yang menarik, yakni tokoh kancil tersebut, terlepas dari berbagai masalah karena dia selalu ingat pada Tuhan dan bersujud seperti layaknya manusia. Dari sikapnya yang religius inilah ia selalu mendapat solusi sewaktu tertimpa masalah. Data cerita ini penulis dapatkan dari majalah Mangle, No.168, Maret 1969, tidak ada nama pengarangnya (anonim/NN). Mengenai cerita binatang atau cerita fauna atau fabel, Sarumpaet (2010) mengatakan bahwa cerita binatang dianggap sebagai cerita tertua karena binatang dianggap makhluk yang sejak awal banyak dihadapi dan bergaul dengan manusia. Cerita binatang digunakan sebagai perlambang dan teladan tentang hidup manusia. Di sisi lain, fabel merupakan kisah didaktik yang mengandung moral. Cerita yang menggunakan binatang sebagai gambaran manusia utuh itu diciptakan oleh Aesop (berasal dari Yunani).

Terkait fungsi fabel Damono mengatakan, bahwa cerita binatang yang kita temui di mana pun rupanya diciptkan terutama untuk memenuhi fungsi didaktifnya. Di Indonesia, binatang yang sangat populer sebagai tokoh fiksi didaktik adalah kancil. Binatang ini begitu cerdik sehingga dengan berbagai jenis tipu muslihat ia senantiasa mampu melepaskan diri dari bahaya yang mengancam jiwanya. Ia bisa mengatasi segala jenis binatang lain, mulai dari ular sampai gajah. Namun, dalam salah satu episod kisahnya ia terpaksa harus mengakui keunggulan akalakalan binatang lain, yakni siput, dalam sebuah lomba lari. Kisah kancil tampaknya memang diciptakan untuk menyampaikan nasihat, namun ditinjau dari satu segi kisah ini juga bisa ditafsirkan mengandung sindiran yang tajam terhadap hegemoni kaum kuat terhadap yang lemah, hal yang hanya dapat diatasi jika yang tertindas memiliki akal. Berbagai jenis binatang juga diciptakan untuk menyampaikan pesan yang antara lain meliputi keagamaan, adat, dan etika dalam kehidupan bermasyarakat ( Damono, 2005).

Jadi inti dari cerita binatang menurut Sapardi Djoko Damono, yaitu memiliki fungsi didaktik. Di samping itu, fabel diciptakan untuk menyampaikan nasihat dan sindiran.

Upaya menggali religiusitas dari cerita binatang akan memperlihatkan kekayaan khasanah cerita binatang. Melalui pengenalan dan pemahaman nilai-nilai religiusitas tersebut dari cerita binatang itu diharapkan pesan yang terdapat di dalamnya bisa dijadikan acuan atau tuntunan dalam menjalankan kehidupan.

Penelitian atas cerita binatang ini telah dilakukan, antara lain oleh Mardiyanto "Cerita Kancil dalam Sastra Nusantara: Teks dan Analisis Perbandingan Motif" (1999), Mardiyanto 1999. "Cerita Kancil dalam Sastra Nusantara: Teks dan Analisis Perbandingan Motif." Jakarta: Pusat Pembinaan dan Pengembangan Bahasa. Jaruki "Telaah Struktur Cerita Nusantara: Cerita Burung" (2002), Siti Zahra Yundiafi "Unsur Didaktis dalam Cerita Nusantara: Kera dan Kancil" (2001), "Unsur Didaktis dalam Cerita Nusantara: Harimau" (2002). Masalah dalam tulisan ini 


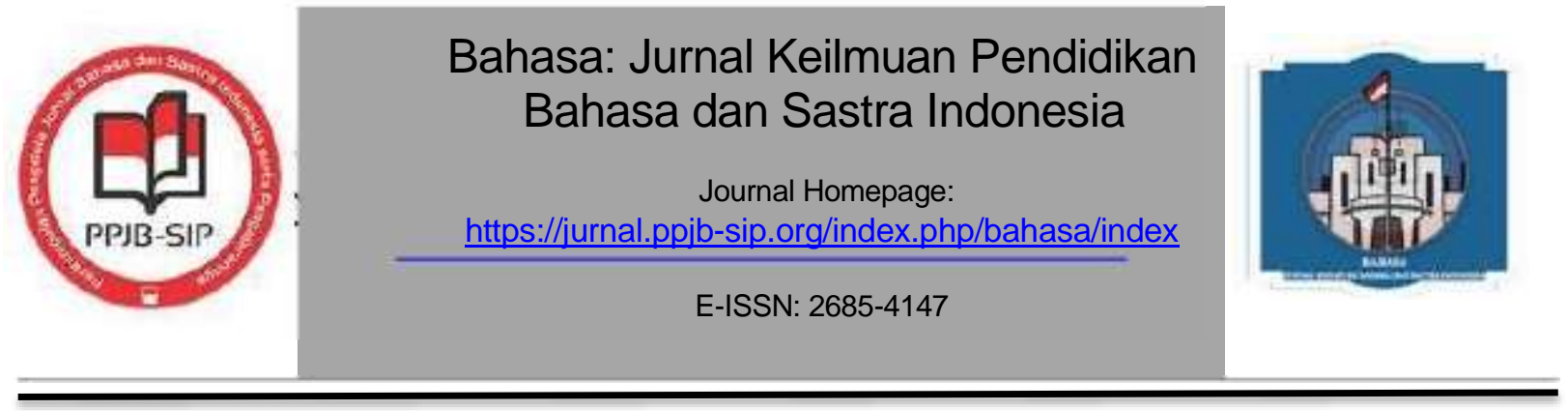

adalah wujud atau bentuk religiusitas (nilai-nilai religius) seperti apa yang disampaikan dalam cerita tersebut dan bagaimana cara pengarang (yang anonim) itu menyampaikan pesannya.

\section{METODE PENELITIAN}

Metode yang digunakan dalam tulisan ini adalah metode deskriptif analitis. Metode tersebut digunakan dengan cara-cara mendeskripsikan fakta-fakta, kemudian disusul dengan analisis atau tidak semata-mata menguraikan, juga memberikan pemahaman dan penjelasan (Ratna, 2007). Metode ini dipilih karena yang dilakukan dalam analisis ini adalah mendeskripsikan nilai-nilai religius dalam cerita "Seekor Kancil yang Selalu Ingat Kepada Tuhan".

Ada tiga komponen analisis data, yaitu reduksi data, sajian data, dan verifikasi (Huberman \& Milles, 2007). Adapun langkah-langkah penelitian ini sebagai berikut.

1. Reduksi data meliputi penentuan data penelitian dan membuat gambaran cerita dalam cerita lisan.

2. Sajian data meliputi mendeskripsikan, menganalisis data melalui tokoh dan perwatakan dan penarikan kesimpulan. Pendeskripsian dilakukan dengan mendeskripsikan, menganalisis data melalui tokoh dan perwatakan yang berhubungan dengan budi pekerti atau karakter. Analisis data dilakukan dengan cara menghubungkan tokoh dengan perwatakannya untuk mendapatkan pesan moral yang ada dalam cerita.

3. Verifikasi data

Teknik pengumpulan data yang digunakan dalam penelitian ini adalah studi pustaka. Selanjutnya fabel "Seekor Kancil yang Selalu Ingat Kepada Tuhan" akan dianalisis dengan pendekatan objektif yang menitik beratkan pada karya itu sendiri (Abrams dalam A.Teeuw, 1984). Penulis mengupas unsur intrinsik cerita "Seekor Kancil yang Selalu Ingat Kepada Tuhan" kemudian mengaitkannya dengan unsur religius si tokoh utama.. Mengenai religiusitas (religiositas) pengertiannya adalah perasaan keagamaan. Yang dimaksud dengan perasaan keagamaan ialah segala perasaan batin yang ada hubungannya dengan Tuhan. Contohnya, perasaan dosa (guilt feeling), perasaan takut ( fear to God), kebesaran Tuhan (God's glory) dalam (Subijantoro Atmosuwito, 2010). Dalam KBBI (2008:1158) pengertian religiositas adalah pengabdian terhadap agama dan kesalehan. Berkaitan dengan religiusitas dalam cerita "Seekor Kancil yang Selalu Ingat Kepada Tuhan" yang dimaksud adalah perasaan batin yang berupa kesalehan dari sang tokoh yang selalu berhubungan dengan Tuhan.

\section{HASIL DAN PEMBAHASAN}

\section{Analisis dan Pembahasan}

Berikut tabel yang menggambarkan unsur-unsur intrinsik seperti, tokoh dan penokohan, latar, tema, dan pesan atau amanat cerita. 
Bahasa: Jurnal Keilmuan Pendidikan Bahasa dan Sastra Indonesia Vol 3 No 2 (2021) (Hal: 90 - 102)

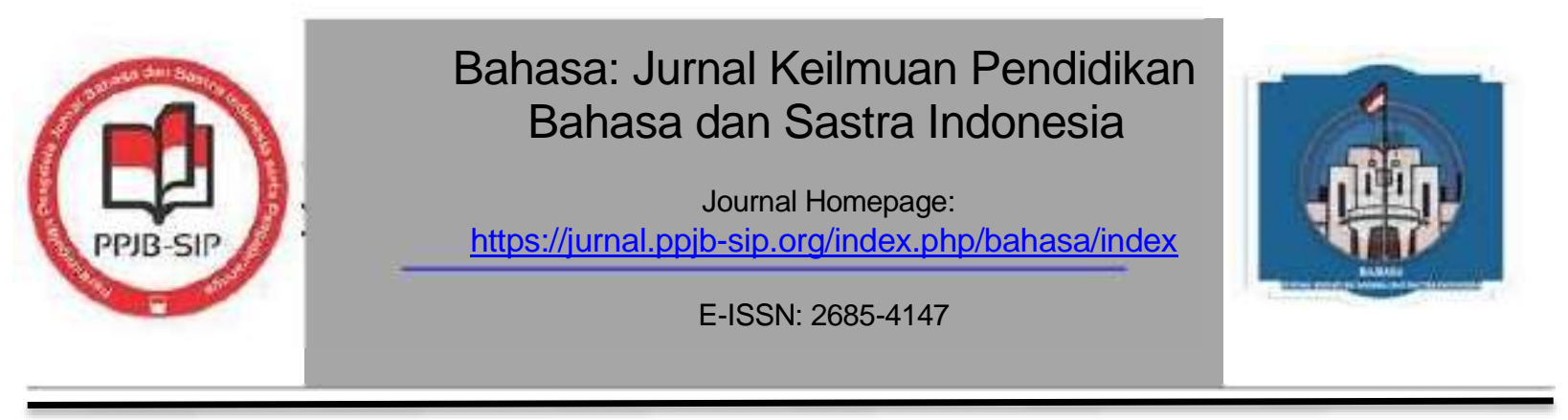

Tabel 1. Unsur Intrinsik “Cerita Seekor Kancil yang Selalu Ingat Kepada Tuhan”

\begin{tabular}{|c|c|c|c|c|c|}
\hline $\begin{array}{l}\text { Judul } \\
\text { Cerita }\end{array}$ & Inti Cerita & $\begin{array}{l}\text { Tokoh dan } \\
\text { penokohan }\end{array}$ & $\begin{array}{c}\text { Latar } \\
\text { tempat } \\
\text { dan } \\
\text { waktu }\end{array}$ & Tema & Pesan \\
\hline $\begin{array}{l}\text { Seekor } \\
\text { Kancil } \\
\text { Yang } \\
\text { Selalu } \\
\text { Ingat } \\
\text { Kepada } \\
\text { Tuhan }\end{array}$ & $\begin{array}{l}\text { Musim kemarau tiba. } \\
\text { Sawah dan sungai sudah } \\
\text { mengering. Begitu juga } \\
\text { dengan tumbuh- } \\
\text { tumbuhan. } \\
\text { Seekor kancil sangat } \\
\text { kehausan. Ia mencari air } \\
\text { tetapi tidak dapat. } \\
\text { Kancil berdoa, bersujud } \\
\text { memohon pertolongan } \\
\text { Tuhan. Samar-samar dari } \\
\text { jauh Kancil melihat } \\
\text { gerombulan pepohonan } \\
\text { di sebuah bukit. } \\
\text { Kancil menuju bukit. } \\
\text { Tempat itu ternyata } \\
\text { cukup jauh. Ia melewati } \\
\text { kebun ilalang yang baru } \\
\text { saja dibakar orang, badan } \\
\text { kancil kotor terkena } \\
\text { debu. } \\
\text { Kancil sampai ke bukit. } \\
\text { Dia menemukan sumber } \\
\text { mata air dan rerumputan. } \\
\text { Sebelum minum dan } \\
\text { makan Kancil bersujud } \\
\text { mengucapkan terima } \\
\text { kasih atas pertolongan } \\
\text { Tuhan. Setelah itu dia } \\
\text { minum dan makan } \\
\text { rumput. }\end{array}$ & $\begin{array}{l}\text { Kancil (tokoh } \\
\text { utama) } \\
\text { wataknya } \\
\text { tidak mudah } \\
\text { putus asa, } \\
\text { bersikap } \\
\text { tenang, penuh } \\
\text { semangat, } \\
\text { selalu ingat } \\
\text { Tuhan } \\
\text { (berdoa) } \\
\text { Tokoh Macan } \\
\text { (maung) dan } \\
\text { Serigala } \\
\text { digambarkan } \\
\text { sebagai } \\
\text { binatang yang } \\
\text { akan } \\
\text { memangsa } \\
\text { kancil. Kedua } \\
\text { binatang itu, } \\
\text { sebagai } \\
\text { binatang yang } \\
\text { kuat/raja } \\
\text { rimba, } \\
\text { pemberani, } \\
\text { dan tidak ada } \\
\text { yang mau } \\
\text { mengalah. } \\
\text { Tokoh }\end{array}$ & $\begin{array}{l}\text { Di sebuah } \\
\text { hutan } \\
\text { gundul } \\
\text { dan } \\
\text { pohon- } \\
\text { pohonnya } \\
\text { banyak } \\
\text { yang mati } \\
\text { karena } \\
\text { musim } \\
\text { kemarau } \\
\text { (musim } \\
\text { katiga) } \\
\text { yang } \\
\text { sangat } \\
\text { panjang. }\end{array}$ & $\begin{array}{l}\text { Pentingnya } \\
\text { selalu } \\
\text { ingat } \\
\text { Tuhan }\end{array}$ & $\begin{array}{l}\text { Hendaknya } \\
\text { selalu } \\
\text { ingat akan } \\
\text { Tuhan } \\
\text { supaya } \\
\text { hidup } \\
\text { selamat } \\
\text { dan } \\
\text { beruntung }\end{array}$ \\
\hline
\end{tabular}


Bahasa: Jurnal Keilmuan Pendidikan Bahasa dan Sastra Indonesia Vol 3 No 2 (2021) (Hal: 90 - 102)

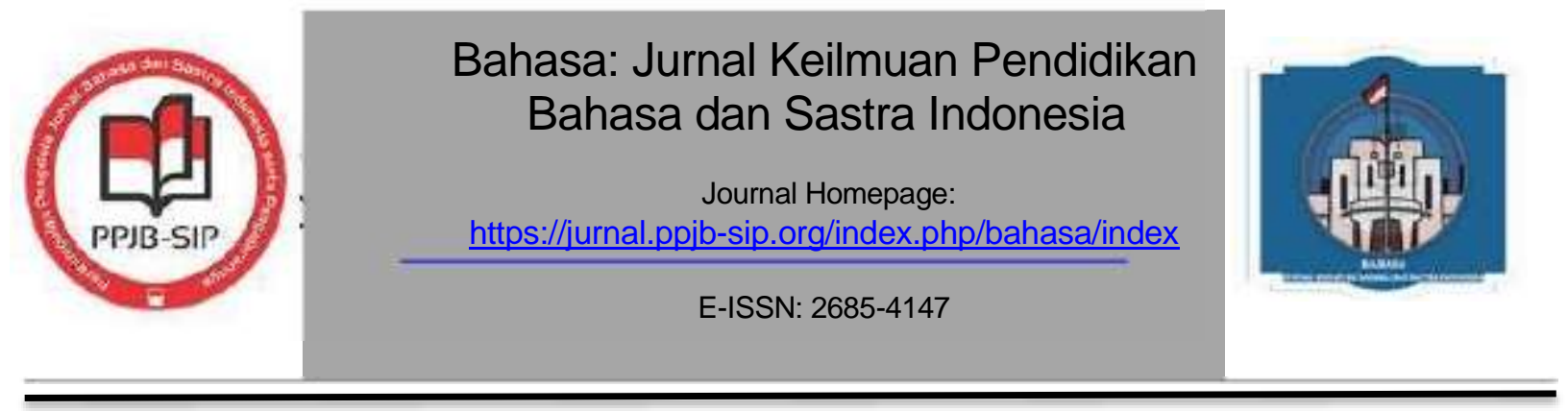

Di belakang kancil ada Serigala juga

seekor serigala yang emosional,

memburunya. Setelah kurang

dekat, serigala itu ragu- cermat dalam

ragu karena badan kancil melihat objek

yang belang-belang kotor sasaran, dan

itu seperti anak harimau. peragu.

Sementara, kepalanya Tokoh Macan

seperti kepala kancil. Jadi binatang

serigala itu hanya pengintai

mengawas-awasai saja. yang cermat,

Ternyata yang berbuat ia mengintai

seperti itu tidak hanya buruannya

serigala,juga seekor dari atas

macan/harimau (maung) pohon

yang tengah ngintip di

atas sebuah pohon.

Kancil tenang-

tenang saja karena tidak mengetahui dirinya

dijadikan rebutan dua binatang pemangsa.

Macan dari atas dahan

loncat ke hadapan kancil.

Ia takut keduluan

serigala.

Serigala marah kepada macan. Sebaliknya macan juga marah karena merasa terganggu.

Kancil sangat kaget dan takut karena di hadapannya ada dua hewan pemangsa yang memperebutkan dirinya. Kancil sujud dan berdoa. 


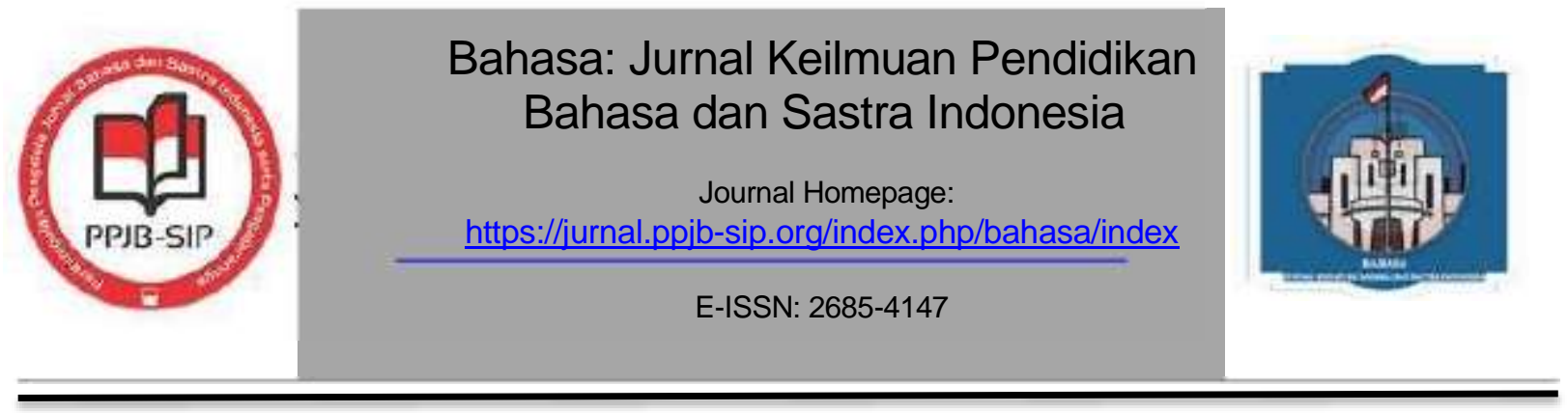

\section{Tokoh dan Penokohan, Tema, latar, dan Pesan}

Dari tabel tersebut dapat dianalisis, bahwa watak tokoh utama (Kancil) itu merupakan tokoh yang tidak mudah putus asa dalam menghadapi situasi yang sulit sekalipun (kelaparan, tidak ada makanan dan minuman, pada musim kemarau yang panjang, musim katiga). Sementara, Serigala dan Macan/harimau (maung) yang biasa disebut sebagai si raja hutan merupakan sosok tokoh binatang pemangsa yang mengincar si Kancil. Sebagai sosok pemangsa, ia tidak mempedulikan perasaan si korban yang peuh ketakutan, bagi si pemangsa yang penting tujuannya tercapai. . Pengarang menampilkan latar tempat yang pas/sesuai dengan dunia binatang/fauna) yakni di hutan, bukit, sawah. Begitu pula dalam menggambarkan latar waktu, sebagai penanda waktu pengarang tidak menyebut secara detail, hanya disebutkan musim katiga, yakni musim kemarau yang sangat panjang.

Tema cerita fabel "Seekor Kancil yang Selalu Ingat Kepada Tuhan" adalah pentingnya selalu mengingat Tuhan. Cara pengarang (yang anonim) menyampaikan nilai-nilai religiusnya terkesan tidak menggurui atau vulgar. Melalui perwatakan para binatang, latar cerita dan jalinan cerita pembaca dapat menangkap pesan atau amanat pengarang (anonim) dalam cerita bahwa selalu ingat pada Tuhan akan membawa keberuntungan.

\section{Religiusitas}

Berikut segala perasaan batin yang ada hubungannya dengan Tuhan, seperti perasaan perasaan takut, perasaan bersyukur, kebesaran Tuhan (God's glory), dan lain-lain.

Tabel 2. Religiusitas dalam Cerita "Seekor Kancil yang Selalu Ingat Tuhan"

Perasaan batin tokoh

Kancil sangat sedih dan

lemas karena kelaparan
Aksi tokoh

Duduk sujud dan berdoa seperti manusia memuja Tuhan

Kancil merasa senang Duduk sujud dan berdoa karena mendapat rezeki seperti manusia (dia menemukan sumber mata air dan rumput di atas bukit

Kancil sangat takut karena dijadikan rebutan oleh

\section{Nilai-Nilai religius}

-berdoa meminta

pertolongan

-memuja Tuhan

(Tuhan tempat meminta pertolongan)

-bersyukur

(Tuhan tempat bersyukur) 


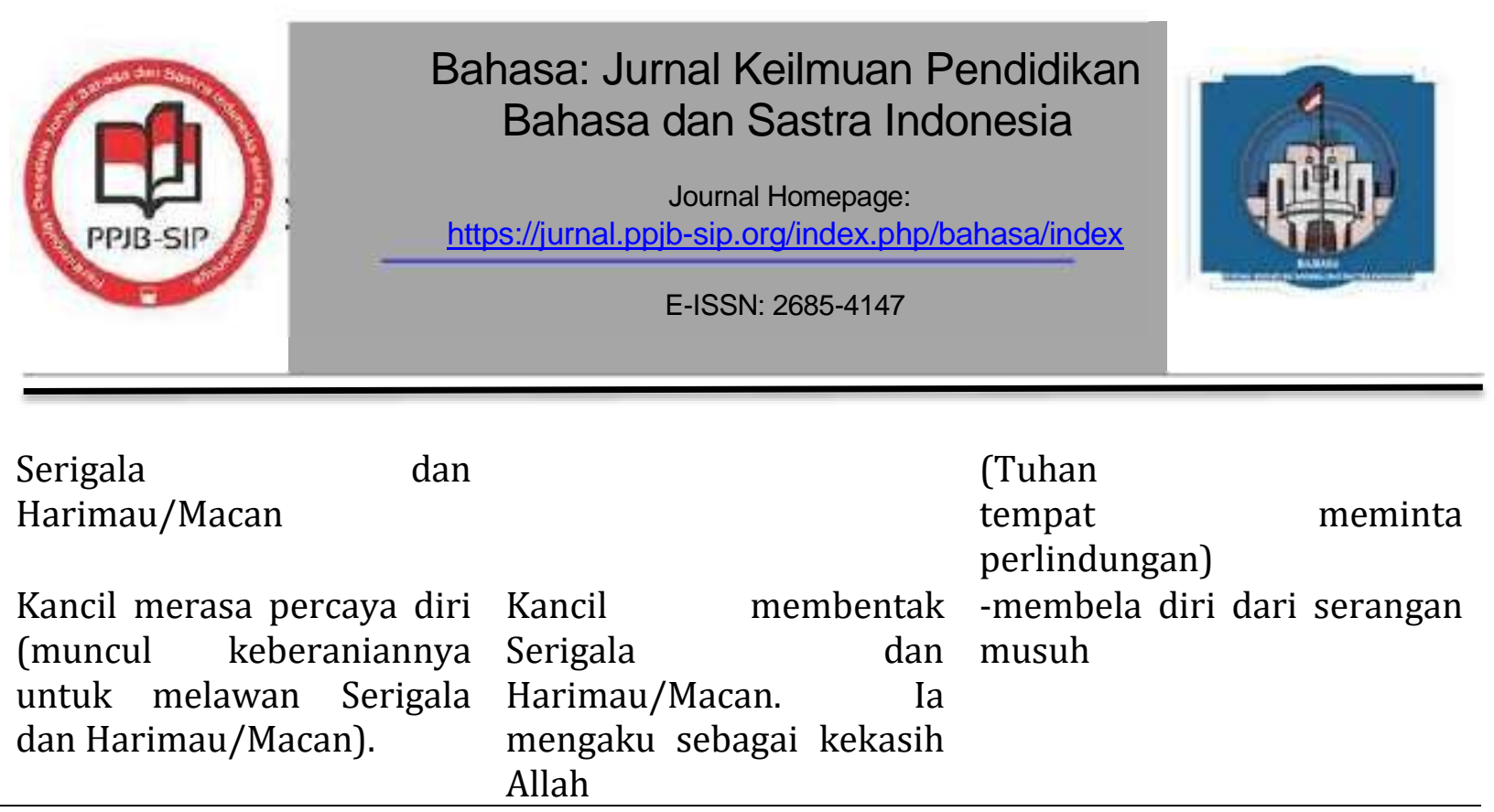

Dalam cerita "Seekor Kancil yang Selalu Ingat Kepada Tuhan “, sebagai tokoh utama Kancil jantan selalu menunjukkan sikap religiusnya di dalam menghadapi persoalan. Pertama pada saat dia sangat kehausan dan kelaparan, tetapi tidak ada air setetes pun untuk diminum dan tidak ada rumput untuk dimakan. Pada saat itu musim kemarau tengah melanda hutan yang ia tinggali, istilahnya musim katiga. Sikap Kancil dalam menunjukkan kereligiusannya, yakni dengan cara berdoa dan bersujud meminta pertolongan kepada Tuhan pada saat tidak memiliki apa-apa. Ini sesuai dengan konsep religiusitas adalah perasaan keagamaan sang tokoh. Walaupun sangat berat dalam menjalani hidup ternyata sang Kancil tidak berkeluh kesah, tetapi dia cepatcepat berdoa memohon pertolongan kepada Tuhannya.

Mentjek djalu keur djadjaka tandukna karek nongtot,katalimbeng hajang nginum. ...Si Mentjek susah djeung leuleus. Si Mentjek susah djeung leuleus. Bru njuuh deku tjara manusa. Hatena djumerit neda pitulung Nu Agung, sangkan dipaparinan manggih tjai djeung djukut. ... (NN, 1969:33).

Sikap religius Kancil berikutnya, ditunjukkan dengan cara melakukan sujud syukur sewaktu mendapatkan rezeki tersebut. Setelah berjalan jauh, kancil itu menemukan gerombulan pepohonan di sebuah bukit yang cukup jauh. Dia harus melewati ladang ilalang yang baru saja dibakar manusia. Badannya jadi kotor terkena abu ilalang tersebut. Pertolongan Tuhan pun segera datang dan dia dapat terlepas dari penderitaan hidupnya itu. Selanjutnya, di bukit itu kancil mendapat rezeki nomplok, yaitu air dan rumput dan dia tidak buru-buru minum dan memakannya, tetapi Kancil jantan itu pertama kali sujud kepada Tuhan mengucapkan terima kasih, bersyukur.

...Tas sudjud, lapat-lapat di anu djauh bet nendjo aja gerembel-gerembel ngarunggunuk tatangkalan subur.....

Ari djol teh enja bae aja tjai mani ngagentjlang herang. Geuning aja sedong tjinjusu nu angger ngotjorna njeboran djukut-djukut sabudeureunana. ... 


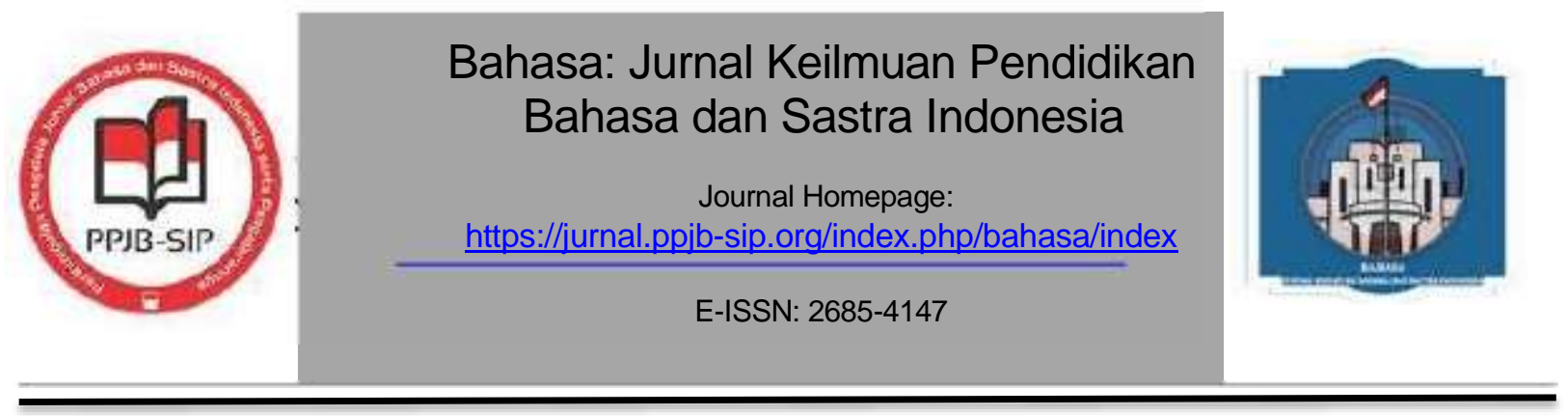

Ki budjang Mentjek manggih tjai manggih djukut nu seger teh teu geuwat2 kop. Teu rusuh2 nginum, nadjan tikorona geus garing ge, teu geura2 njatuan. Tapi sudjud deui ka Nu Agung, nganuhunkeun heula (NN, 1969:33).

Kancil itu bersyukur mendapatkan rezeki air dan rumput pada saat musim kemarau panjang. Setelah bersujud ia baru minum pelan-pelan. Jadi sebelum makan dan minum pun dia bersyukur dulu pada Tuhan. Selanjutnya Kancil kembali menunjukkan kereligiusannya, pada saat ketakutan dihadapkan pada dua binatang pemangsa (Serigala dan Harimau/Macan) yang sedang mengincarnya, kemudian bertengkar memperebutkan sang Kancil. Sang Kancil dalam keadaan ketakutan dan tidak berdaya/pasrah/berserah diri pada Tuhan. Dia berdoa dan sujud seperti manusia.

Sadjero dua berhala silih herongan. Ki Mentjek sudjud deui njambat ka Pangeran, He Allah Nu Maha Alus

Allah Nu Maha Sampurna

Allah Nu aja salawasna

Allah $\mathrm{Nu}$ Maha welas asih,

Allah Nu Uninga

Allah $\mathrm{Nu}$ aja di mana-mana

Allah Nu Maha Kawasa.

Abdi si Mentjek teu daja teu upaja, neda disalametkeun ku Gusti, tina ieu bahaja Adjag sareung Maung anu bade ngamangsa ...

Geus seubeuh mah biur bae Ki Mentjek teh kabur ngajauhan, salamet. Bari teu poho dina hatena jen Allah nu njipta sakumna kaadjaiban alam (NN,1969:34).

Pada saat terlepas dari mara bahaya (musuh yang mengintai) Kancil berdoa dan bersujud syukur kepada Tuhan.

Dari analisis atas nilai-nilai religiusitas dalam cerita "Seekor Kancil yang Selalu Ingat Kepada Tuhan" dapat ditemukan bentuk kereligiusan secara singkat, yakni keyakinan kuat atas kebesaran Tuhan, Tuhan tempat mengadu dan meminta pertolongan, selalu berdoa, berserah diri kepada Tuhan, hidup penuh syukur, memohon ampunan kepada Tuhan, serta membela diri saat diserang musuh.

\section{Makna Cerita}

Dari watak dan perilaku tokoh dapat diinterpretasikan bahwa bisa saja si Kancil ini merupakan representasi orang kecil yang beruntung karena selalu ingat Tuhan. Sementara, si Serigala dan Harimau/Macan tampil sebagai representasi orang "besar" yang "menjalankan" 


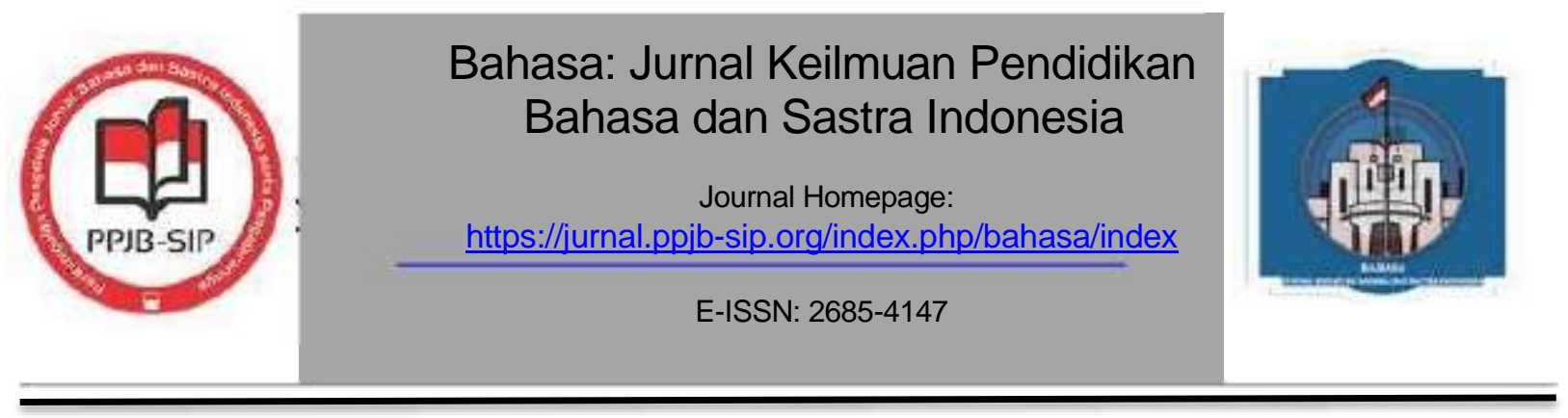

hukum rimba (yang kuat berkuasa dan akan "memangsa" yang kecil). Namun, dalam cerita ini, hukum rimba tidak terjadi karena si tokoh utama selalu ingat Tuhan dan meminta perlindunganNya. Tampaknya ini pesan penting pengarang dalam fabel ini. Di sisi lain bisa juga nasihat atau moral cerita bagi manusia bahwa dalam hidup harus selalu ingat Tuhan supaya selamat dan beruntung.

\section{KESIMPULAN}

Hasil pembahasan atas fabel "Seekor Kancil yang Selalu Ingat Kepada Tuhan" didapatkan nilai -nilai religiusitas yang dituangkan dalam bentuk perilaku tokoh cerita yang hidupnya dalam koridor kesalehan seorang makhluk atas Tuhannya. Fabel ini juga memenuhi fungsi didaktisnya yakni melalui pesan pengarang bahwa selalu ingat Tuhan akan membawa keberuntungan. Di samping itu, nilai-nilai religiusitas dalam cerita "Seekor Kancil yang Selalu Ingat Kepada Tuhan" terwujud dalam bentuk (1) keyakinan kuat atas kebesaran Tuhan, (2) Tuhan tempat mengadu dan meminta pertolongan, (3) selalu berdoa, (4) berserah diri kepada Tuhan, (5) hidup penuh syukur, (6) memohon ampunan kepada Tuhan, serta (7) membela diri saat diserang musuh. Dalam kehidupan binatang di rimba raya, biasanya terjadi hukum rimba, yang kuat menang yang lemah kalah, tetapi dalam cerita binatang "Seekor Kancil yang Selalu Ingat Kepada Tuhan" hukum rimba tidak terjadi karena sang protagonis (Kancil) selalu ingat Tuhan dan sang antagonis, musuhnya-musuhnya pada akhirnya mati.

Sosok Kancil versus Serigala dan Harimau/Macan bisa diinterpretasikan bahwa Kancil bisa sebagai representasi orang kecil dan Serigala dan Harimau/Macan sebagai orang besar yang tengah mengintai kelemahan orang kecil. Akhir cerita, sosok orang kecil ini beruntung karena selalu ingat dan ditolong Tuhan.

\section{DAFTAR PUSTAKA}

Atmosuwito, Subijantoro. (2010, cet 2.). Perihal Sastra \& Religiusitas dalam Sastra. Bandung: Sinar Baru Algensindo.

Damono, Sapardi Djoko. (2005). Pegangan Penelitian Sastra Bandingan. Jakarta: Pusat Bahasa, Departemen Pendidikan Nasional.

Danandjaja, James. (1984). Folklor Indonesia, Ilmu Gosip, Dongeng, dan Lain-Lain.Jakarta: Grafiti.

Darma, Budi. (2007). Sastra Moral dan Kreativitas. Surabaya: Unesa Press.

Huberman, A.M. \& Matthew B. M. (2007). Analisis Data Kualitatif. (terjemahan Tjetjep Rohendi Rohidi). Jakarta: UI Press 
Bahasa: Jurnal Keilmuan Pendidikan Bahasa dan Sastra Indonesia Vol 3 No 2 (2021) (Hal: 90 - 102)

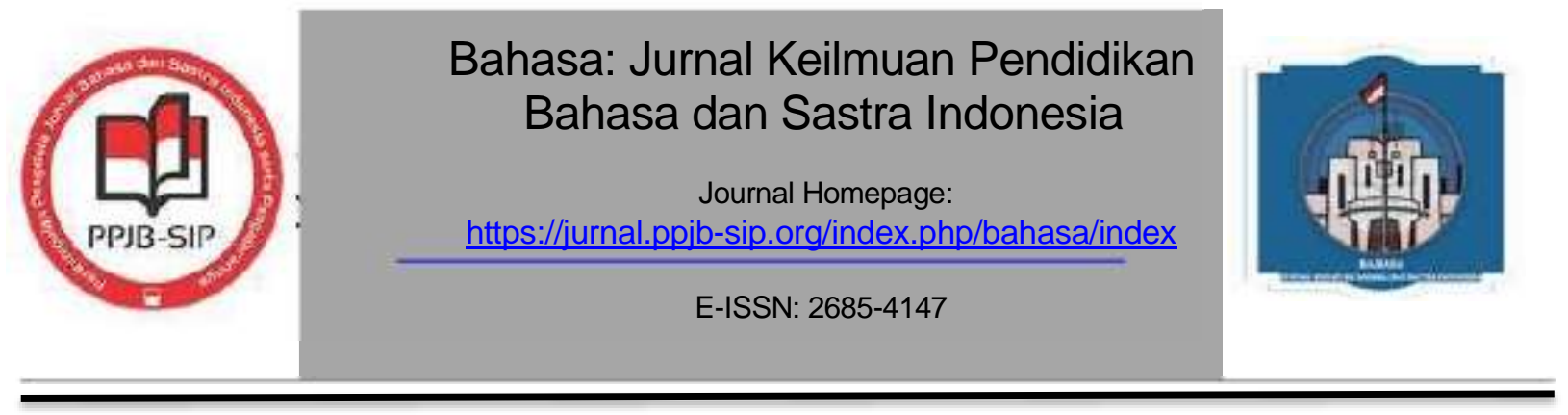

Jaruki, Muhamad. (2012). Aspek Pendidikan Dalam Antologi Cerita Binatang Dari Tanah Papua. Yogyakarta: Lokus.

Mardiyanto. (1999). Cerita Kancil dalam Sastra Nusantara: Teks dan Analisis Perbandingan Motif. Jakarta: Pusat Pembinaan dan Pengembangan Bahasa, Departemen Pendidikan dan Kebudayaan.

Ratna, Nyoman Kutha. (2007). Teori, Metode dan Teknik Penelitian Sastra . Yogyakarta: Pustaka Pelajar.

Sarumpaet, Riris K. Toha. (2010). Pedoman Penelitian Sastra Anak. Jakarta: Pusat Bahasa, Kemendiknas.

Supardo, Nursinah. (1975). Kesusastraan Indonesia (cet. Ketiga). Jakarta: Tunas Mekar Murni.

Teeuw, A. (1984). Sastra dan Ilmu Sastra Pengantar Teori Sastra. Jakarta: Pustaka Jaya.

Tim KBBI. (2008). Kamus Besar Bahasa Indonesia (edisi keempat). Jakarta: Gramedia Pustaka Utama.

Zaidan, Abdul Rozak dkk. 1991. Kamus Istilah Sastra. Jakarta: Pusat Pembinaan dan Pengembangan Bahasa, Departemen Pendidikan dan Kebudayaan. 